\title{
New polymorphic microsatellite markers of the endangered meadow viper (Vipera ursinii) identified by 454 high-throughput sequencing: when innovation meets conservation
}

\author{
César Metzger • Anne-Laure Ferchaud • \\ Céline Geiser · Sylvain Ursenbacher
}

Received: 3 February 2011/Accepted: 13 February 2011/Published online: 3 March 2011

(C) Springer Science+Business Media B.V. 2011

\begin{abstract}
The Next Generation Sequencing (pyrosequencing) technique allows rapid, low-cost development of microsatellite markers. We have used this technology to develop 14 polymorphic loci for the endangered meadow viper (Vipera ursinii). Based on 37,000 reads, we developed primers for 66 microsatellite loci and found that 14 were polymorphic. The number of alleles per locus varies from 1 to 12 (for 30 individuals tested). At a cost of about $1 / 3$ that of a normal microsatellite development, we were able to define enough microsatellite markers to conduct population genetic studies on a non-model species.
\end{abstract}

Keywords Conservation genomics - Microsatellite · Vipera ursinii $\cdot 454$ sequencing

\section{Introduction}

The recent advent of next-generation, high-throughput sequencing technology and the improvement of more

C. Metzger · C. Geiser · S. Ursenbacher $(\varangle)$

Department of Environmental Sciences, Section of Conservation

Biology, University of Basel, St-Johanns-Vorstadt 10,

4056 Basel, Switzerland

e-mail: s.ursenbacher@unibas.ch

Present Address:

C. Metzger

Zoological Institute, University of Basel, Vesalgasse 1,

4051 Basel, Switzerland

\section{A.-L. Ferchaud}

Laboratoire Biogéographie et Ecologie des Vertébrés, Ecole Pratique de Hautes Etudes, Centre d'Ecologie Fonctionnelle et Evolutive CNRS, 1919 Route de Mende, 34293 Montpellier Cedex 5, France traditional techniques has allowed biologists to venture into the study of the population genetic structure of non-model organisms, which was previously so time-consuming and expensive (Abdelkrim et al. 2009; Santana et al. 2009) that a population study of rare and/or cryptic species was rarely attempted. Paradoxically, the importance of studying habitat fragmentation, gene flow and hybridization in such species is higher due to their higher sensitivity to environmental perturbations (e.g. Spielman et al. 2004).

An array of molecular tools has been useful in conservation genetics and some of the most commonly used nowadays are microsatellite markers (Frankham et al. 2002; Goldstein and Schlötterer 1999). In the field of reptile conservation genetics, only a few microsatellite markers for a limited number of species (34; based on GenBank and Mullin and Seigel 2009) are available out of the 3149 snake species listed by the EMBL Reptile Database. Vipers are the most intensively studied group in Europe but specific primers have only been developed for one of them $(V$. berus: Carlsson et al. 2003; Ursenbacher et al. 2009).

The meadow viper (Bonaparte, 1835) is a widespread palaearctic Viperidae ranging from southeastern France to northwestern China. Nonetheless, this species is one of the most threatened snake species in Europe owing to its highly fragmented habitat (Ferchaud et al. 2011). This species is classified as endangered (EN) on the IUCN Red List of Threatened Species, strictly protected under CITES (Appendix I and II) and the Bern Convention. Scientific research has focused on different aspects, including population dynamics (Baron et al. 1996; Ferrière et al. 1996), cohabitation with other species (Agrimi and Luiselli 1992; Luiselli et al. 2007), genetic diversity reduction (Ujvari et al. 2002, 2005) and population fragmentation (Ferchaud et al. 2011). However, no specific microsatellite locus has yet been isolated for this snake. 
Here, we describe the characterization of 15 microsatellite loci for $V$. ursinii using next generation pyrosequencing methods and tested their polymorphism in a French population.

\section{Materials and methods}

We harvested DNA from a stillborn specimen sampled from the population 1 mentioned in Ferchaud et al. (2011). The extraction was done with a Qiagen DNeasy kit and DNA ( $\approx 10-15 \mathrm{ng}$ ) was sent to Microsynth AG (Balgach, Switzerland) for random 454 pyrosequencing and genomic library building. The genomic data was screened for potential microsatellites using MSATCOMMANDER v0.8.2 (Faircloth 2008) and a final selection was based on the length and the homogeneity of their repetitions. Two primers were designed for each selected microsatellite and the results of the PCR were examined by electrophoresis in a $1.5 \%$ agarose gel. A first selection of potential polymorphic loci was done with a QIAxcel machine (Qiagen, Hombrechtikon, Switzerland), using a QIAxcel DNA highresolution kit (Qiagen). Subsequently, polymorphism of the microsatellite loci was tested for 30 samples of the population 3 (Ferchaud et al. 2011) with an ABI Prism 3130XL sequencer. The null allele occurrence was tested for each locus using MICRO-CHECKER v2.2.3 (Van Oosterhout et al. 2004). Observed $\left(H_{\mathrm{o}}\right)$ and expected $\left(H_{\mathrm{e}}\right)$ heterozygosity, deviation from Hardy-Weinberg Equilibrium
(HWE) and genetic disequilibrium were calculated for each genetic marker using FSTAT v2.9.3 (Goudet 1995).

\section{Results and discussion}

The 454 sequencing provided 37,227 reads and MSTATCOMMANDER selected 3228 microsatellite loci (Table 1). Similar numbers of di-, tri- and tetranucleotide microsatellites were detected with a higher number of repetitions for dinucleotides (mean, minimum-maximum repetitions 12.8, $6-193$; 8.64, 4-27; and 8.10, 4-42, respectively). We designed primer pairs for 66 microsatellite loci, but PCR products were obtained from only 44 microsatellite loci. A first test of polymorphism with the QIAxcel system suggested that 15 markers could be polymorphic.

Finally, primer pairs were combined to allow the amplification of all loci in five multiplex PCR reactions in order to amplify up to 4 loci in the same $10 \mu \mathrm{l}$ PCR reaction (PCR conditions are given in Table 2). The number of alleles per locus ranged from 1 (Vu11 and Vu36) to 12 (Vu58) with expected heterozygosity values in the range $0.000-0.859$ (Table 1). Only 1 (Vu52) microsatellite loci tested showed evidence of null alleles and HWE deviation. No evidence of genetic disequilibrium was detected.

The microsatellite markers developed in this work will be useful for the study of gene flow and inbreeding in the meadow viper. Based on the high throughput available

Table 1 Summary of the methodological test used to develop microsatellite markers from random sequencing using a next generation sequencer (454 pyrosequencing) and the proportion of usable microsatellite loci at each step

\begin{tabular}{|c|c|c|}
\hline Step & No. microsatellite loci & Remarks \\
\hline $\begin{array}{l}\text { Random sequencing on 1/16th plate } \\
\text { of a } 454 \text { sequencer (Roche) }\end{array}$ & Reads: 37,227 & Mean length: 316.2 bp \\
\hline $\begin{array}{l}\text { Selection of microsatellites using } \\
\text { MSATCOMMANDER v0.8.2 } \\
\text { (Faircloth 2008) }\end{array}$ & $\begin{array}{l}\text { Microsatellite loci: } 3228 \\
\text { (but only } 2462 \text { for which } \\
\text { potential primers could be } \\
\text { designed) }\end{array}$ & $\begin{array}{l}\text { Dinucleotides: } 762 \\
\text { Trinucleotides: } 780 \\
\text { Tetranucleotides: } 920\end{array}$ \\
\hline $\begin{array}{l}\text { Secondary selection of microsatellite } \\
\text { loci with a long and stable number } \\
\text { of repeats }\end{array}$ & Microsatellite loci: 66 & $\begin{array}{l}\text { Dinucleotides: } 25 \\
\text { Trinucleotides: } 21 \\
\text { Tetranucleotides: } 20 \\
\text { This selection was subjective and numerous additional } \\
\text { microsatellite loci could have been tested }\end{array}$ \\
\hline $\begin{array}{l}\text { Amplification and control of PCR } \\
\text { product on agarose gel }\end{array}$ & Microsatellite loci: 44 & $\begin{array}{l}\text { After a few PCR tests with different temperatures and } \mathrm{MgCl}_{2} \\
\text { concentration, we were unable to amplify } 22 \text { microsatellite loci } \\
\text { with a clear and repeatable signal }\end{array}$ \\
\hline $\begin{array}{l}\text { Polymorphism test with QIAxcel } \\
\text { system (Qiagen) }\end{array}$ & $\begin{array}{l}\text { Microsatellite loci polymorphic: } \\
15 \text { of the } 44\end{array}$ & \\
\hline $\begin{array}{l}\text { Polymorphism test with capillary } \\
\text { sequencer }\end{array}$ & $\begin{array}{l}\text { Microsatellites polymorphic in the } \\
\text { population } 3 \text { (Ferchaud et al. 2011): } \\
13 \text { of the } 15\end{array}$ & $\begin{array}{l}\text { One non-polymorphic microsatellite locus in population } 3 \text { is } \\
\text { polymorphic in other populations (Ferchaud pers. comm.) }\end{array}$ \\
\hline
\end{tabular}




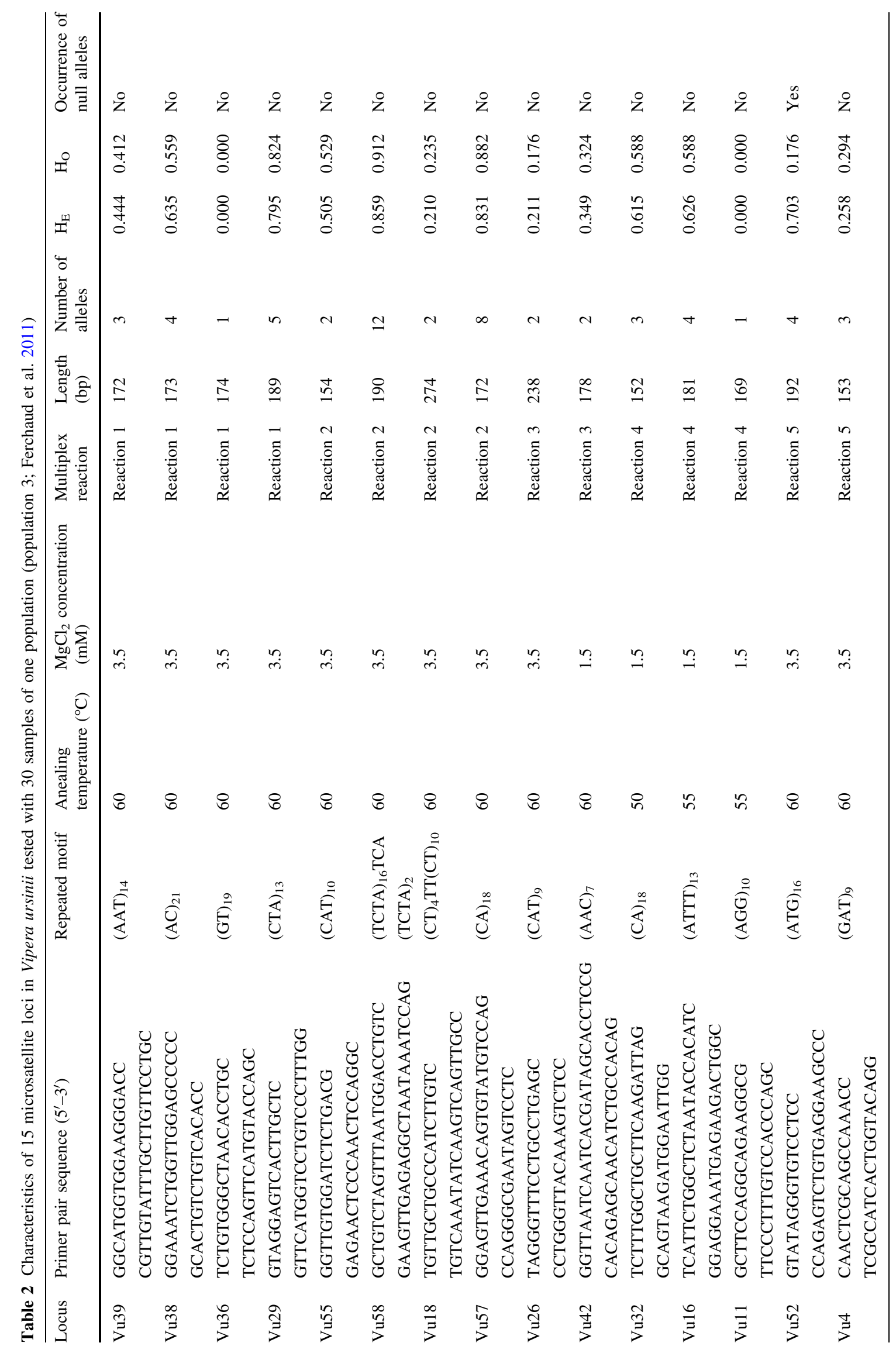


using next generation sequencing, the rapid development of numerous microsatellite loci can be achieved with limited cost (in this study, the cost was about 1/3 that of a normal order). In addition, this method can provide hundreds of polymorphic primers (in our case, $21 \%$ of the developed loci were polymorphic) for non-model organisms. Consequently, we recommend that scientists interested in population genetics use this methodology to reduce developmental costs of new microsatellite markers for nonmodel species.

Acknowledgments The authors are grateful to Jean-Pierre Baron and Arnaud Lyet for providing the samples and thank Matthieu Raemy and Hans-Peter Rusterholz (University of Basel) for help in the laboratory. Polymorphism was tested through the molecular genetic analysis technical facilities of the IFR119 "Montpellier Environnement Biodiversité".

\section{References}

Abdelkrim J, Robertson B, Stanton JA, Gemmell N (2009) Fast, costeffective development of species-specific microsatellite markers by genomic sequencing. Biotechniques 46:185-192

Agrimi U, Luiselli L (1992) Feeding strategies of the Viper Vipera ursinii ursinii (Reptilia, Viperidae) in the Apennines. Herpetolog J 2:37-42

Baron JP, Ferrière R, Clobert J, Saint Girons H (1996) Life history of Vipera ursinii ursinii at Mont-Ventoux (France). C R Acad Sci Ser III 319:57-69

Carlsson M, Isaksson M, Hoggren M, Tegelström H (2003) Characterization of polymorphic microsatellite markers in the adder, Vipera berus. Mol Ecol Notes 3:73-75

Faircloth BC (2008) MSATCOMMANDER: detection of microsatellite repeat arrays and automated, locus-specific primer design. Mol Ecol Resour 8:92-94

Ferchaud A-L, Lyet A, Cheylan M, Arnal V, Baron JP, Mongelard C, Ursenbacher S (2011) High genetic differentiation among French populations of the Orsini's meadow viper (Vipera ursinii ursinii) based on mitochondrial and microsatellite data: implications for conservation management. J Hered 102:67-78

Ferrière R, Sarrazin F, Legendre S, Baron JP (1996) Matrix population models applied to viability analysis and conservation: theory and practice using the ULM software. Acta Oecol Int J Ecol 17:629-656

Frankham R, Ballou JD, Briscoe DA (2002) Introduction to conservation genetics. Cambridge University Press, Cambridge

Goldstein DB, Schlötterer C (1999) Microsatellites: evolution and applications. Oxford University Press, Oxford

Goudet J (1995) FSTAT (Version 1.2): a computer program to calculate F- statistics. J Hered 86:485-486

Luiselli L, Filippi E, Di Lena E (2007) Ecological relationships between sympatric Vipera aspis and Vipera ursinii in highaltitude habitats of central Italy. J Herpetol 41:378-384

Mullin SJ, Seigel RA (2009) Snakes: ecology and conservation. Cornell University, New York

Santana Q, Coetzee M, Steenkamp E, Mlonyeni O, Hammond G, Wingfield M, Wingfield B (2009) Microsatellite discovery by deep sequencing of enriched genomic libraries. Biotechniques 46:217-223

Spielman D, Brook BW, Frankham R (2004) Most species are not driven to extinction before genetic factors impact them. Proc Natl Acad Sci USA 101:15261-15264

Ujvari B, Madsen T, Kotenko T, Olsson M, Shine R, Wittzell H (2002) Low genetic diversity threatens imminent extinction for the Hungarian meadow viper (Vipera ursinii rakosiensis). Biol Conserv 105:127-130

Ujvari B, Madsen T, Olsson M (2005) Discrepancy in mitochondrial and nuclear polymorphism in meadow vipers (Vipera ursinii) questions the unambiguous use of mtDNA in conservation studies. Amphib Reptil 26:287-292

Ursenbacher S, Monney J-C, Fumagalli L (2009) Limited genetic diversity and high differentiation among the remnant adder (Vipera berus) populations in the Swiss and French Jura Mountains. Conserv Genet 10:303-315

Van Oosterhout C, Hutchinson WF, Wills DPM, Shipley P (2004) MICRO-CHECKER: software for identifying and correcting genotyping errors in microsatellite data. Mol Ecol Notes 4: $535-538$ 